\title{
Analysis of the proteinases of Trypanosoma brucei
}

\author{
Colin D. Robertson, ${ }^{1}$ Michael J. North, ${ }^{2}$ Barbara C. Lockwood ${ }^{1}$ and \\ GrahaM H. COOMBS ${ }^{1 *}$ \\ ${ }^{1}$ Department of Zoology, University of Glasgow, Glasgow G12 8QQ, UK \\ ${ }^{2}$ Department of Biological and Molecular Sciences, School of Natural Sciences, University of Stirling, \\ Stirling FK9 4LA, UK
}

(Received 19 October 1989; revised 18 December 1989; accepted 26 January 1990)

\begin{abstract}
A method comprising enzyme separation by SDS-PAGE and subsequent use of peptidyl aminomethylcoumarins as substrates has been used to study proteinases of the protozoan parasite Trypanosoma brucei. The application of this method has allowed investigation of the substrate specificities of individual proteinases in cell lysates without the need for enzyme purification. The results show that $T$. brucei contains a group of cysteine proteinases, probably four in number, with substrate and inhibitor specificities similar to those of cathepsin $L$. A second group of proteinases, larger enzymes with significantly different substrate specificities and sensitivity to inhibitors, was also detected. Peptidyl diazomethanes inhibited the cysteine proteinases and also parasite growth, offering promise that peculiarities in the substrate specificity of trypanosomal cysteine proteinases could be exploited by compounds of this type.
\end{abstract}

\section{Introduction}

A lot is known about the structure and activity of mammalian and plant cysteine proteinases (Barrett et al., 1988; Koehler \& Ho, 1988). The advent of families of specific irreversible inhibitors such as the peptidyl diazomethanes (Crawford et al., 1988) makes this group of enzymes attractive targets for chemotherapeutic attack. Many important parasitic protozoa have been shown to contain multiple cysteine proteinases of high activity (Lockwood et al., 1987; North et al., 1990). The overall aim of our studies is to gain greater knowledge and understanding of the cysteine proteinases of parasitic flagellates with a view to elucidating their functional significance to the parasites and exploiting their presence by the design of specific inhibitors or pro-drugs. The investigations should also provide greater insight into the diversity and evolution of cysteine proteinases and how the different parts of the enzyme contribute to the overall catalytic activity.

Previous studies on trypanosomes have shown that they contain multiple proteinases, including both cysteine and serine types, and have provided some

Abbreviations: Boc, $\mathrm{N}$-tert-butoxycarbonyl; Bz, $\mathrm{N}$-benzoyl; $\mathrm{CHN}_{2}$, diazomethane; E-64, L-3-carboxy-2,3-trans-epoxypropionyl-leucylamido-(4-guanidino)butane; glut, glutaryl; NHMec, 7-(4-methyl)coumarylamide; suc, $\mathrm{N}$-succinyl; $\mathrm{Z}, \mathrm{N}$-benzyloxycarbonyl. information on their subcellular location and substrate specificity (North et al., 1983; Lonsdale-Eccles \& Mpimbaza, 1986; Lonsdale-Eccles \& Grab, 1987; Pamer et al., 1989; Sakanari et al., 1989). Recently, we reported that a cysteine proteinase gene of $T$. brucei differs significantly from those encoding mammalian cysteine proteinases in that the gene sequence predicts that the trypanosomal enzyme contains a C-terminal extension with no equivalent in mammalian enzymes (Mottram $e t$ al., 1989). In order to determine whether or not this structural feature affects the activity of the enzyme, we wished to study in detail the substrate specificity of cysteine proteinases of the parasite. To enable this to be done without the need to purify the individual enzymes present, we have applied a method that allows investigations of individual enzymes in cell lysates. In this paper we report the results obtained by using this method for a study on $T$. brucei.

\section{Methods}

Chemicals. All reagents were of the finest grade available. $Z$-arg-argNHMec (ZRR-NHMec), H-leu-val-tyr-NHMec (LVY-NHMec), Acala-ala-tyr-NHMec (AcAAY-NHMec), H-pro-phe-arg-NHMec (PFRNHMec), glut-gly-arg-NHMec (GlutGR-NHMec), Z-pro-argNHMec (ZPR-NHMec), Z-arg-NHMec (ZR-NHMec), Z-phe-ala$\left.\mathrm{CHN}_{2}(\mathrm{ZFA}-\mathrm{CHN})_{2}\right)$ and Z-phe-phe-CHN $\mathrm{CHF}_{2}\left(\mathrm{ZFF}-\mathrm{CHN}_{2}\right)$ were obtained from Bachem. Boc-val-leu-lys-NHMec (BocVLK-NHMec), 
Boc-phe-ser-arg-NHMec (BocFSR-NHMec), Bz-phe-val-arg-NHMec (BzFVR-NHMec), Z-phe-arg-NHMec (ZFR-NHMec), Z-gly-gly-argNHMec (ZGGR-NHMec), suc-leu-tyr-NHMec (SucLY-NHMec), suc-ala-phe-lys-NHMec (SucAFK-NHMec), suc-gly-pro-leu-gly-proNHMec (SucGPLGP-NHMec), gelatin, fibrinogen, DTT and proteinase inhibitors were obtained from Sigma.

Organisms. Long slender bloodstream and procyclic forms of Trypanosoma brucei AnTat 1.3 from stock EATRO 1125 were used for most of the studies. Long slender bloodstream forms of $T$. brucei IsTat 1.A were used in some experiments as indicated. Procyclic forms were grown axenically in vitro in Brun's medium (Brun \& Schonenberger, 1979) at $26^{\circ} \mathrm{C}$ and harvested when at a density of $1-2 \times 10^{7} \mathrm{ml}^{-1}$ by centrifugation at $1000 \mathrm{~g}$ for $10 \mathrm{~min}$. The collected cells were washed twice in phosphate-buffered saline $(0.05 \mathrm{M}$-sodium phosphate, $0.15 \mathrm{M}$ $\mathrm{NaCl}, \mathrm{pH} 7.3$ ) and used immediately or stored at $-70^{\circ} \mathrm{C}$ until required. Bloodstream forms were grown in Wistar rats, harvested when at high parasitaemia and $>99 \%$ long slender forms by the method of Lanham \& Godfrey (1970) and used immediately or stored at $-70{ }^{\circ} \mathrm{C}$ until required. Cell lysates were prepared by suspending cells in $0.25 \mathrm{M}$-sucrose with $0.25 \%$ Triton X-100, vortexing and centrifuging at $10000 \mathrm{~g}$ for $5 \mathrm{~min}$. The resultant supernatant fraction was used for all analyses.

Proteinase analyses. Soluble enzymes were separated using SDSPAGE and their activity in situ towards peptidyl aminomethylcoumarins was determined by monitoring the release of the fluorescent product. Cell extracts (2-4 mg protein $\mathrm{ml}^{-1}$ ) were mixed with an equal volume of electrophoresis sample buffer $(62.5 \mathrm{mM}-\mathrm{Tris} / \mathrm{HCl}, \mathrm{pH} 6.8$, containing $2 \%, \mathrm{w} / \mathrm{v}$, SDS, $5 \%, \mathrm{v} / \mathrm{v}, 2$-mercaptoethanol, $10 \%, \mathrm{w} / \mathrm{v}$, sucrose and $0.002 \%$ bromophenol blue) before electrophoresis on $7.5 \%$ $(\mathrm{w} / \mathrm{v})$ acrylamide $/ 0.2 \%$ gelatin SDS-PAGE gels in a Bio-Rad miniProtean system. The resolved gels were incubated with shaking in $2.5 \%$ (v/v) Triton $\mathrm{X}-100$ for $30 \mathrm{~min}$ at room temperature. The gels were then preincubated for $5 \mathrm{~min}$ at $37^{\circ} \mathrm{C}$ in $0.1 \mathrm{M}$-Tris/ $\mathrm{HCl}, \mathrm{pH} 8.0$, or $0.1 \mathrm{M}$ sodium acetate/acetic acid, pH 5.5, containing 1 mm-DTT. Subsequently, the aminomethylcoumarin was added to a final concentration of $10 \mu \mathrm{M}$ and incubation continued. Stock solutions $(5 \mathrm{mM})$ of the aminomethylcoumarins were prepared in water except for ZFRNHMec and SucLY-NHMec (both in 20\%, v/v, acetonitrile), BzFVRNHMec $(50 \%, v / v$, acetonitrile), ZR-NHMec $(60 \%, v / v$, acetonitrile), AcAAY-NHMec (glacial acetic acid), ZPR-NHMec $(60 \%, v / v$, methanol) and GlutGR-NHMec $(80 \%, v / v$, methanol). Hydrolysis of substrates was detected by placing the gels on a ChromatoVue model TL-23 UV-Transilluminator and recording the fluorescence using a Polaroid camera fitted with a Kodak Wratten gelatin filter (number 2E). Sufficient sample was loaded onto the gels to allow detection of the enzymes within $30 \mathrm{~min}$. In most cases, however, activity was observed and recorded within $10 \mathrm{~min}$ of adding the substrate. To detect activity towards the gelatin copolymerized in the gel, incubation was allowed to continue for up to $20 \mathrm{~h}$ at $37^{\circ} \mathrm{C}$ whereupon the gel was fixed and stained with Coomassie Blue. In some experiments, the gelatin was replaced by fibrinogen at $0.25 \%$.

The effects of the peptidyl diazomethanes and E-64 on the proteinase activities were examined by preincubating the cell extracts with the inhibitors for $1 \mathrm{~h}$ at $18^{\circ} \mathrm{C}$. The same inhibitors were used after electrophoresis by including them in the incubation buffer at $10 \mu \mathrm{M}$. Leupeptin $\left(5 \mu \mathrm{g} \mathrm{m}^{-1}\right)$, PMSF (0.35 mM), o-phenanthroline (1 mM) and cystatin $\left(4 \mu \mathrm{g} \mathrm{m}^{-1}\right)$ were similarly tested by inclusion after the electrophoresis.

Effects of diazomethanes on growth of procyclic forms. The antitrypanosomal activities of the compounds were determined by adding them to in vitro cultures of procyclic forms in microtitre plates. Doubling concentrations in the range $1-100 \mu \mathrm{g} \mathrm{m}^{-1}$ were used; stock solutions were prepared in DMSO. Incubation was for $72 \mathrm{~h}$ at $25^{\circ} \mathrm{C}$ whereupon

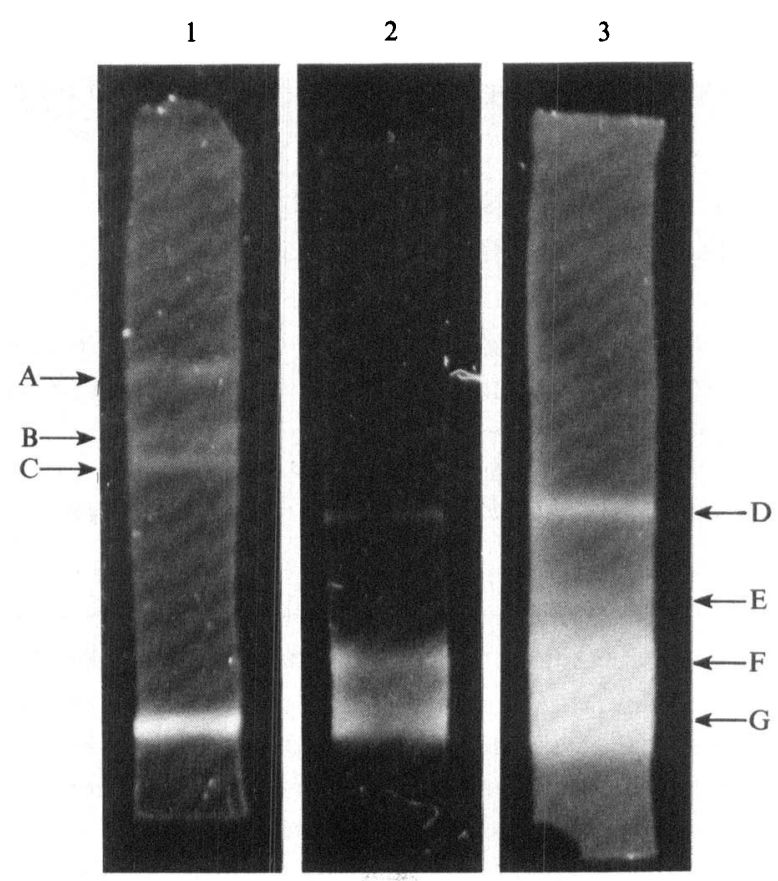

Fig. 1. Proteinases detected using fluorogenic substrates. An extract $(250 \mu \mathrm{l})$ from bloodstream forms of $T$. Brucei was mixed with the same volume of electrophoresis sample buffer and loaded across the whole width of a gelatin-SDS-PAGE mini-gel. The gel was run and stained as described in Methods. Track 1, gel strip incubated with PFR-NHMec for $10 \mathrm{~min}$; tracks 2 and 3, strips incubated with ZFR-NHMec for 5 and $30 \mathrm{~min}$, respectively.

the parasite densities were determined. Only non-inhibitory concentrations of DMSO were used.

\section{Results}

Seven proteinases could be distinguished when extracts of long slender bloodstream forms of $T$. brucei were analysed (Fig. 1). The use of fluorogenic substrates allowed detection of enzymes (labelled D and E) which were not apparently active towards gelatin or fibrinogen and another enzyme $(F)$ which had only very low activity towards gelatin. All seven activities were observed only when large amounts of protein were loaded onto the gels. Enzymes B and C frequently appeared as a single band, whereas $D$ and $E$ were seen only with freshly prepared extracts. Enzyme G, which had higher activity than $F$ towards peptide substrates, was also detected using gelatin SDS-PAGE, although it was more active towards fibrinogen, and appears to correspond to the $27 / 28 \mathrm{kDa}$ enzyme reported by other workers (Lonsdale-Eccles \& Grab, 1987; Pamer et al., 1989). As the same proteinase activities were detected at both $\mathrm{pH} 5.5$ and 8.0 , subsequently all experiments were done at $\mathrm{pH} \quad 8.0$. Activities A, B/C, F and G were also observed, albeit at 


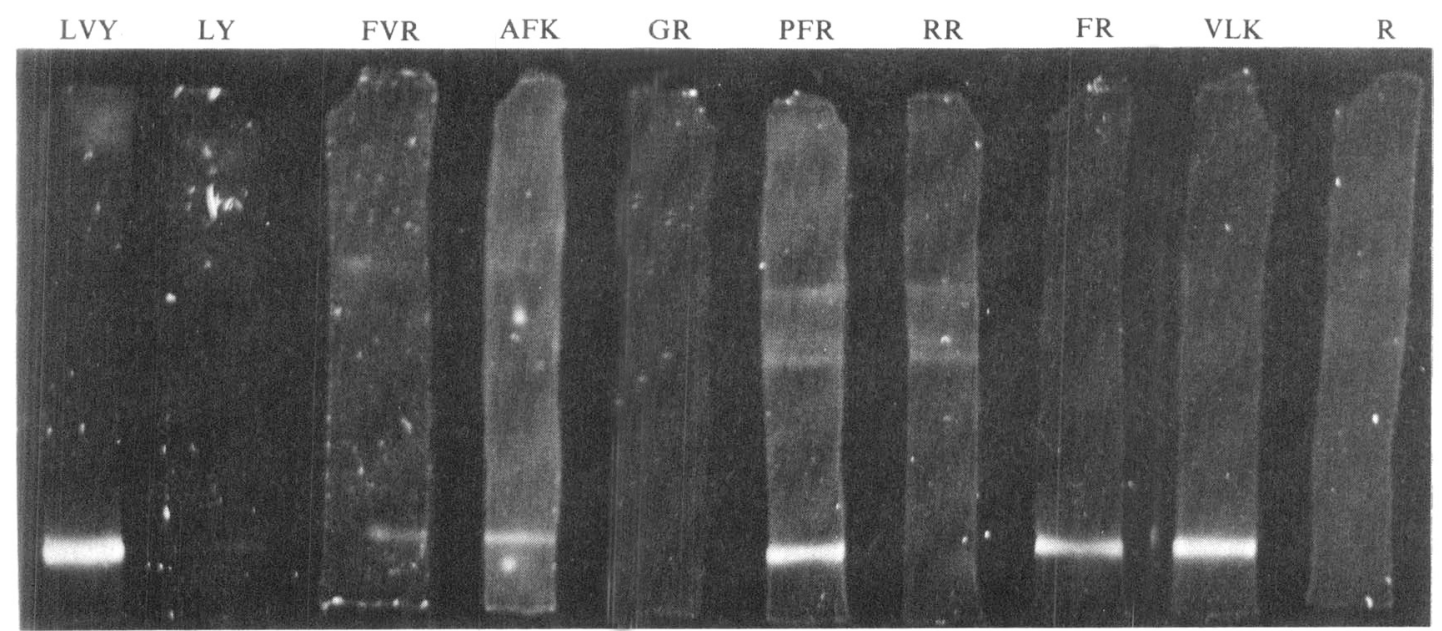

Fig. 2. Activity of proteinases towards different substrates. A gel was run and stained as detailed in Fig. 1. The strips were incubated for 10 min with the substrates as indicated. They were (from left to right): LVY-NHMec; SucLY-NHMec; BzFVR-NHMec; SucAFKNHMec; GlutGR-NHMec; PFR-NHMec; ZRR-NHMec; ZFR-NHMec; BocVLK-NHMec; ZR-NHMec.

lower activity, in extracts of procyclic forms. $\mathrm{G}$ was the most active. Comparative studies with extracts of long slender bloodstream forms of $T$. brucei IsTat 1.A revealed the presence of activities $A, B / C, F$ and $G$, although $\mathrm{F}$ was much less active than in the other line.

The enzyme activities detected appeared to fall into two groups. The proteinases of the lower-molecular-mass group (D, E, F and G) all had similar substrate specificities (Table 1). Typical results for enzyme $G$ are shown in Fig. 2. The use of inhibitors showed that $F$ and

Table 1. Activities of proteinases towards peptidyl aminomethylcoumarins

Proteinase activity towards substrates was graded from high $(+++)$ to none $(-) ;+/-$ represents very low activity. The comparisons were made within each group of proteinases and the results are the consensus from several experiments.

\begin{tabular}{lrr}
\hline \hline & \multicolumn{2}{c}{ Proteinases } \\
\cline { 2 - 3 } \multicolumn{1}{c}{ Substrate } & $\mathrm{A}, \mathrm{B}, \mathrm{C}$ & $\mathrm{D}, \mathrm{E}, \mathrm{F}, \mathrm{G}$ \\
\hline PFR-NHMec & ++ & +++ \\
ZFR-NHMec & + & +++ \\
BocVLK-NHMec & + & +++ \\
SucAFK-NHMec & +1 & ++ \\
LVY-NHMec & - & ++ \\
SucLY-NHMec & - & ++ \\
ZRR-NHMec & ++ & + \\
BzFVR-NHMec & + & + \\
BocFSR-NHMec & +- & - \\
ZGGR-NHMec & ++ & $+1-$ \\
ZR-NHMec & + & - \\
GlutGR-NHMec & + & - \\
ZPR-NHMec & ++ & - \\
AcAAY-NHMec & - & - \\
SucGPLGP-NHMec & - & + \\
\hline \hline
\end{tabular}

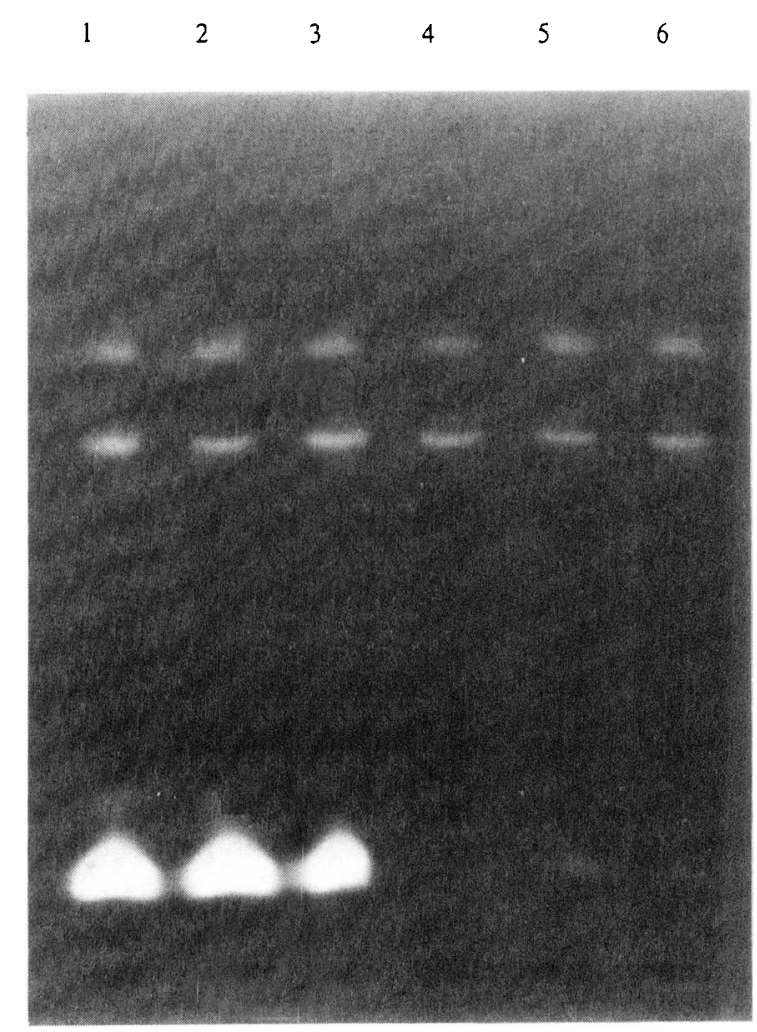

Fig. 3. Effect of inhibitors on proteinase activity. An extract $(25 \mu \mathrm{l})$ from bloodstream $T$. brucei was mixed with $65 \mu \mathrm{l} 0.25 \mathrm{M}$-sucrose containing $0.25 \%$ Triton X-100 and incubated for $1 \mathrm{~h}$ at $18{ }^{\circ} \mathrm{C}$ with $10 \mu \mathrm{l}$ of inhibitor or solvent as a control. The samples were then mixed with $50 \mu \mathrm{l}$ of sample buffer and subjected to electrophoresis. Subsequently, the gel was washed with Triton X-100, incubated at $\mathrm{pH} 5.5$ for $20 \mathrm{~h}$ at $37^{\circ} \mathrm{C}$ to allow the gelatin to be digested, and stained with Coomassie Blue. Track 1, water; 2, 50\% (v/v) DMSO; 3, acetonitrile; $4,10 \mathrm{mM}-\mathrm{E}-$ 64 in water; $5,1 \mathrm{mM}-\mathrm{ZFF}-\mathrm{CHN}_{2}$ in acetonitrile ; 6, 0.5 mM-ZFA-CHN in $50 \%(\mathrm{v} / \mathrm{v})$ DMSO. 
G have characteristics of cysteine proteinases. Preincubation of cell lysates with the diazomethanes or E-64 resulted in marked inhibition of the enzymes whether visualized by gelatin digestion (Fig. 3) or the use of the fluorogenic substrate PFR-NHMec (data not shown). Addition of inhibitors to the buffer used for incubating the gel after electrophoresis showed that both enzymes were inhibited by the diazomethanes, E-64, leupeptin and cystatin but not by PMSF or $o$-phenanthroline.

Enzymes A, B and C were similar to each other and had substrate preferences markedly different from those of the cysteine proteinases (Table 1). They were unaffected by diazomethanes, E- 64 and cystatin but were inhibited to an extent by PMSF and leupeptin. Addition of leupeptin at $10 \mu \mathrm{g} \mathrm{ml}^{-1}$ to the parasites before lysis resulted in a significantly greater activity of these enzymes as detected on gels (leupeptin is removed from proteinases during electrophoresis) whereas bands $\mathrm{D}, \mathrm{E}$, $F$ and $G$ were unaffected.

The two diazomethanes inhibited the growth in vitro of the procyclic forms of $T$. brucei. ZFF- $\mathrm{CHN}_{2}$ was the more effective. At $100 \mu \mathrm{g} \mathrm{ml}^{-1}$ it reduced the number of parasites present at the end of the incubations by $70 \pm$ $3 \%$ whereas $\mathrm{ZFA}-\mathrm{CHN}_{2}$ at the same concentration resulted in a $58 \pm 2 \%$ reduction. The minimum concentrations causing $50 \%$ reductions in parasite numbers were 25 and $50 \mu \mathrm{g} \mathrm{ml}^{-1}$, respectively.

\section{Discussion}

The combination of fluorogenic peptidyl aminomethylcoumarins and SDS-PAGE provides a good method for investigating the substrate specificity of individual enzymes in cell lysates. A particular advantage is that information can be obtained about the enzymes without the need to purify them. Clearly, there are limits to the usefulness of the procedure and for many types of investigation, such as when quantitative data are required, enzyme purification will still be essential. It is also possible that some proteinases may be inactivated during the procedure and so not be detected, whereas others may not be separated during electrophoresis. We have been able to show, however, in our studies on leishmanial proteinases, that two enzymes that run together on gelatin gels can be distinguished by their relative activities towards different fluorogenic substrates (unpublished). The molecular mass values obtained through use of the method should be treated with some caution, as the procedure does not involve boiling with SDS. Another limitation is that only proteinases of relatively high activity can be investigated easily as the product of the hydrolysis is soluble and so permeates throughout the gel and buffer with time. Nevertheless, the method has potential applications in studies of all cell types and we have recently successfully applied it to the study of a variety of other protozoa including trichomonads (North et al., 1990).

As we report in this paper, the method also enabled us to extend the previous findings on substrate specificities of the proteinases of T. brucei (North et al., 1983; Lonsdale-Eccles \& Mpimbaza, 1986; Lonsdale-Eccles \& Grab, 1987) by investigating the specificities of individual enzymes. Use of the method with $T$. brucei has revealed proteinases not apparently active towards gelatin or fibrinogen. The results show that $T$. brucei contains at least two cysteine proteinases (bands $F$ and G) and the similarity in substrate specificity suggests that $\mathrm{D}$ and $\mathrm{E}$ may also be members of this group. The four enzymes shared the same preference for peptides, with the $P_{2}$ and $P_{3}$ residues (Schechter \& Berger, 1967) apparently being important factors in determining enzyme specificity. The results demonstrate that the cysteine proteinases of this parasite resemble cathep$\sin \mathrm{L}$ with respect to their preferences for amino acids in the $P_{2}$ position. This correlates well with the structure predicted from the sequenced trypanosome gene (Mottram et al., 1989), for all the key residues of cathepsin L which by comparison with the papain sequence would be expected to be involved in the $\mathbf{P}_{2}$ pocket (Brocklehurst, 1987) are also encoded in the trypanosome sequence. None of the other evidence obtained so far has revealed unusual features of the specificity of the trypanosomal enzymes. Nevertheless, the unusual C-terminal extension of the trypanosomal enzyme is likely to be reflected in the activity of the enzyme and so other features of substrate specificity should be explored. The results so far suggest that bulky, hydrophobic amino acids may be preferred for the $\mathrm{P}_{3}$ position although the precise preferences must be investigated more fully using analogous series of peptide substrates. Unfortunately such compounds are not yet available. It would also be informative to study the specificity of the enzymes for amino acids in the $\mathrm{P}^{\prime}$ positions. When this information has been obtained, it should be possible to design peptidyl diazomethanes or similar inhibitors with a high degree of specificity for the trypanosomal enzyme. The finding that the two diazomethanes used in this study inhibited the growth of the parasites confirms the potential of this approach as a means of obtaining antitrypanosomal agents.

The results so far have not revealed differences between the four lower-molecular-mass enzymes other than in their apparent size. It is not known whether they are all products of the same gene which are posttranscriptionally modified or if they are transcribed from different members of the multiple cysteine proteinase genes (Mottram et al., 1989). The enzymes are clearly 
different, however, from the other three detected (A, B and C). These enzymes are clearly not cysteine proteinases as is demonstrated by their insensitivity to a variety of inhibitors. It is most probable that they are of the serine type; it was recently confirmed that trypanosomes contain genes for serine proteinases (Sakanari et al., 1989). It is quite possible that trypanosomes contain more enzymes than those detected in this study. Proteinases inactivated during SDS-PAGE would not be observed and others may not be stable in cell lysates. The finding that enzymes $\mathrm{A}, \mathrm{B}$ and $\mathrm{C}$ were protected by leupeptin suggests that many trypanosomal proteins may be rapidly degraded by the cysteine proteinases of this parasite. Inhibitors of these enzymes not only have potential as chemotherapeutic agents but also have a crucial role in experimental studies of trypanosomal proteins.

We thank Dr C. M. R. Turner of the Department of Zoology, University of Glasgow, for providing the bloodstream trypanosomes and Dr R. W. Mason of Strangeways Laboratory, Cambridge, for suggestions on the use of fluorogenic substrates with electrophoresis. The research was funded in part by the Wellcome Trust.

\section{References}

Barrett, A. J., Buttle, D. J. \& Mason, R. W. (1988). Lysosomal cysteine proteinases. ISI Atlas of Science: Biochemistry 1, 256-260.

BROCKLEHLRST, K. (1987). Acyl group transfer - cysteine proteinases. In Enzyme Mechanisms, pp. 140-158. Edited by M. I. Page \& A. Williams. London: Royal Society of Chemistry.

Brun, R. \& SCHONENBERger, M. (1979). Cultivation and in vitro cloning of procyclic culture forms of Trypanosoma brucei in semidefined medium. Acta Tropica 36, 289-292.
Crawford, C., Mason, R. W., Wikstrom, P. \& Shaw, E. (1988). The design of peptidyldiazomethane inhibitors to distinguish between the cysteine proteinases calpain II, cathepsin $\mathrm{L}$ and cathepsin $\mathrm{B}$. Biochemical Journal 253, 751-758.

KoEHLER, S. \& Ho T.-H. D. (1988). Purification and characterization of gibberellic acid-induced cysteine endoproteases in barley aleurone layers. Plant Physiology 87, 95-103.

LANHAM, S. N. \& Godfrey, D. G. (1970). Isolation of salivarian trypanosomes from man and other mammals using DEAE cellulose. Experimental Parasitology 20, 521-534.

Lockwood, B. C., NoRTh, M. J., Mallinson, D. J. \& CoOmbs, G. H. (1987). Analysis of Leishmania proteinases reveals developmental changes in species-specific forms and a common $68 \mathrm{kDa}$ activity. FEMS Microbiology Letters 48, 345-350.

LonsDale-Eccles, J. D. \& GraB, D. J. (1987). Lysosomal and nonlysosomal peptidyl hydrolases of the bloodstream forms of Trypanosoma brucei brucei. European Journal of Biochemistry 169, 467-475.

Lonsdale-Eccles, J. D. \& Mpimbaza, G. W. N. (1986). Thioldependent proteases of African trypanosomes. European Journal of Biochemistry 155, 469-473.

MotTram, J. C., North, M. J., Barry, J. D. \& CoOmbs, G. H. (1989). A cysteine proteinase cDNA from Trypanosoma brucei predicts an enzyme with an unusual C-terminal extension. FEBS Letters 258 , 211-215.

North, M. J., CoOmbs, G. H. \& BARRY, J. D. (1983). A comparative study of the proteolytic enzymes of Trypanosoma brucei, $T$. equiperdum, T. evansi, T. vivax, Leishmania tarentolae and Crithidia fasciculata. Molecular and Biochemical Parasitology 9, 161-180.

North, M. J., Robertson, C. D. \& CoOMBs, G. H. (1990). The specificity of trichomonad cysteine proteinases analysed using fluorogenic substrates and specific inhibitors. Molecular and Biochemical Parasitology 39, 183-194.

Pamer, E. G., So, M. \& Davis, C. E. (1989). Identification of a developmentally regulated cysteine protease of Trypanosoma brucei. Molecular and Biochemical Parasitology 33, 27-32.

Sakanari, J. A., Staunton, C. E., Eakin, A. E., Craik, C. S. \& McKerrow, J. H. (1989). Serine proteases from nematode and protozoan parasites: isolation of sequence homologs using generic molecular probes. Proceedings of the National Academy of Sciences of the United States of America 86, 4863-4867.

SCHECHTER, I. \& BERGER, A. (1967). On the size of the active site in proteases. I. Papain. Biochemical and Biophysical Research Communications 27, 157-162. 